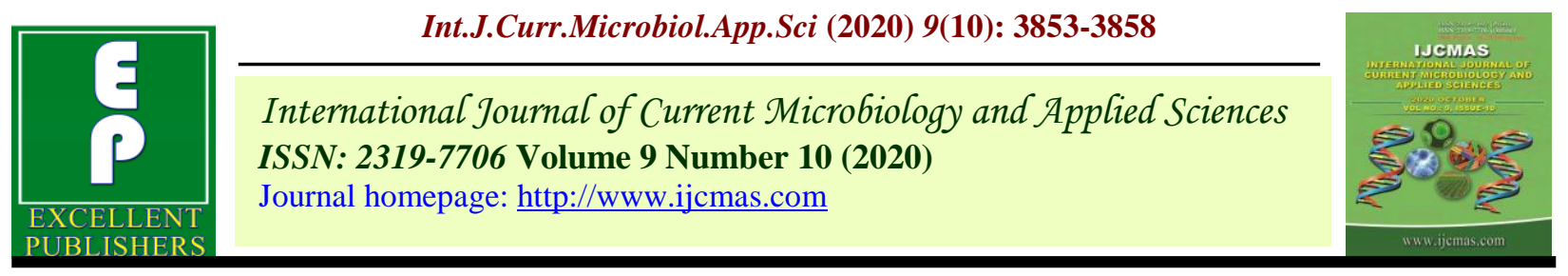

Original Research Article

https://doi.org/10.20546/ijcmas.2020.910.443

\title{
Studies on Anti-fungal Activity of Leaf Extracts of Andrographis echioides (L.) Nees
}

\author{
P. Hemalatha*, V. Sivakumar, R. Parimaladevi and M. Tilak
}

Tamil Nadu Agricultural University, Coimbatore, India

*Corresponding author

\section{A B S T R A C T}

\begin{tabular}{|l|}
\hline K e y w or d s \\
$\begin{array}{l}\text { Andrographis } \\
\text { echioides, Anti- } \\
\text { fungal activity, } \\
\text { Leaf extract, } \\
\text { Inhibition zone }\end{array}$ \\
\hline Article Info \\
\hline $\begin{array}{l}\text { Accepted: } \\
\text { 25 September 2020 } \\
\text { Available Online: } \\
\text { 10 October } 2020\end{array}$ \\
\hline
\end{tabular}

Among all the species of Andrographis, Andrographis echioides is given importance recently for its excellent medicinal properties. The study of Andrographis echioides as anti-microbial agent was found necessary for gaining insight into this medicinal flora and its real value. The ethyl acetate extract of leaves recorded highest anti-fungal activity against all the selected pathogens viz., Pythium aphanidermatum, Phytophthora capsici, Macrophomina phaseolina, Fusarium udum and Aspergillus niger and produced inhibition zone of diameter equal to the positive control. Macrophomina phaseolina and Aspergillus niger were found to be more sensitive to ethyl acetate extract with a MIC value of $100 \mathrm{ppm}$.

\section{Introduction}

Andrographis echioides (L.) Nees (Gopuram thanki) is one of the important medicinal plant species belonging to the family Acanthaceae. Justicia echioides L. and Indoneesiella echioides (L.) Sreemadh are the synonyms of this plant. The plant is an erect, annual herb, simple or slightly branched, growing up to a height of 20 to $60 \mathrm{~cm}$. In the Indian Systems of Medicine predominantly, it is used against blood cancer. The leaf extract is recommended for oral consumption. Traditionally, the plant has been used as febrifuge, bitter tonic, astringent, anodyne and also for dysentery, cholera and diabetes. The chemical constituents of this plant are echioidin and echioidinin (Guhabakshi et al., 1999).

Antibiotics are defined as substances (secondary metabolites) of microbial origin that have anti-microbial activity in very small amounts. It is reported that, on average, two or three antibiotics derived from microbes are launched each year. But the lifespan of such antibiotics is limited. Further, the awareness of problems due to over prescription and misuse of traditional antibiotics is increasing. This has resulted in increasing interest in the anti-microbial plant extracts (Eisenberg et al., 1993). 
Plants have an almost limitless ability to synthesize substances, most of which are phenols or their oxygen-substituted derivatives (Geissman, 1963). Most are secondary metabolites, of which at least 12,000 have been isolated, a number estimated to be less than 10 per cent of the total (Schultes, 1978). In many cases, these substances serve as plant defense mechanisms against predation by microorganisms, insects and herbivores. Since the past research work on antimicrobial aspect is very limited, this study was carried out to determine specifically the antifungal activity of Andrographis echioides (L.) Nees.

\section{Materials and Methods}

The present investigation on photochemical screening of Andrographis echioides (L.) Nees was carried out in Department of Microbiology, Tamil Nadu Agricultural University, Coimbatore.

\section{Planting material}

Leaves of Andrographis echioides (L.) Nees. were collected from Medicinal Plants Unit of Horticultural College and Research Institute, Tamil Nadu Agricultural University, Coimbatore. The leaves were shade dried at room temperature for four to five days.

\section{Extract preparation}

Air dried and powdered plant materials $(0.25$ to $0.5 \mathrm{~kg}$ ) were extracted by maceration and percolation with 70 per cent ethanol, 80 per cent methanol, hexane, dichloromethane, petroleum ether, ethyl acetate, chloroform and water at room temperature. The extracts were then filtered and concentrated under vacuum in rotary evaporator to give (as a percentage of powdered plant materials) 6-11 per cent gummy residue. All the extracts were kept in tightly stoppered bottle in a refrigerator until used for the anti-microbial testing.

\section{Fungi and media}

The plant pathogenic fungal cultures used in this study viz., Pythium aphanidermatum, Phytophthora capsici, Macrophomina phaseolina, Fusarium udum and Aspergillus niger were obtained from Department of Plant Pathology, Tamil Nadu Agricultural University, Coimbatore. Fungi were cultured and maintained on potato dextrose agar at room temperature.

\section{Agar well diffusion method}

The anti-fungal activity of leaf extracts of Andrographis echioides (L.) Nees. was determined by modified agar well diffusion method of Parez et al., (1990). Once the agar was solidified, it was punched with six millimeters diameter wells and filled with 25 $\mu \mathrm{l}$ of the plant extracts and blanks (70\% ethanol, $80 \%$ methanol, hexane, chloroform, dichloromethane, ethyl acetate, acetone and water).

The concentration of the extracts employed was $25 \mu \mathrm{gml}^{-1}$. Simultaneously, ketaconazole was used as positive control at a concentration of $1.0 \mathrm{\mu gml}^{-1}$ respectively. The dilution medium for the positive control was sterile distilled water. The test was carried out in triplicates. The plaques were incubated at room temperature for 48 hours. The antimicrobial activity was calculated by applying the expression.

$$
\operatorname{RIZD}(\%)=\frac{\text { ZZD of sample }- \text { IZD of negative control }}{\text { ZDD of antibiotic standard }} \times
$$

Where,

RIZD is the percentage of relative inhibition zone diameter

IZD is the inhibition zone diameter (mm). 
Minimal inhibitory concentration (MIC) evaluation

The MIC was evaluated on plant extracts that showed anti-microbial activity. This was performed at four concentrations of each extract $(1 \mathrm{ppm}, 10 \mathrm{ppm}, 100 \mathrm{ppm}$ and 1000 ppm) employing the same modified agar well diffusion method.

\section{Results and Discussion}

Anti-fungal activity of different solvent extracts

The treatment $\mathrm{T}_{1} \quad\left(70 \%\right.$ ethanol), $\mathrm{T}_{2}$ (Methanol), $\mathrm{T}_{3}$ (Acetone) and $\mathrm{T}_{6}$ (Ethyl acetate) recorded anti-fungal activity against the selected fungal plant pathogens (Table 1). The ethanol $\left(\mathrm{T}_{1}\right)$ and methanol $\left(\mathrm{T}_{2}\right)$ extracts recorded activity in particular against Fusarium udum and Aspergillus niger whereas acetone extract $\left(\mathrm{T}_{3}\right)$ recorded the activity against Macrophomina phaseolina and Fusarium udum. The ethyl acetate extract $\left(\mathrm{T}_{6}\right)$ recorded the highest activity against all the fungus plant pathogens viz., Pythium aphanidermatum, Phytophthora capsici, Macrophomina phaseolina, Fusarium udum and Aspergillus niger. The positive control (Ketaconazole) recorded activity against all test organisms, while negative control (respective solvents) did not express any activity.

In accordance with these results, it was clear that andrographolides, which were present in the ethyl acetate fraction, could be considered responsible for the anti-microbial activity. Atta-ur-Rahman and Choudhary (1995) stated that diterpenoid alkaloids are commonly found to have anti-microbial properties. Similarly, Ghosh et al., (2004) reported that the crude protein extract from the leaves of Andrographis paniculata was found to inhibit the spore germination of two major pathogens Aspergillus flavus and Macrophomina phaseolina. The anti-fungal protein component was further purified from the crude extract and the molecular mass of toxic protein was estimated to be $39.5 \mathrm{KDa}$.

Table.1 Anti-fungal activity of different solvent extracts of Andrographis echioides (L.) Nees leaves

\begin{tabular}{|l|c|c|c|c|c|}
\hline \multicolumn{1}{|c|}{ Test samples } & \multicolumn{5}{|c|}{ Test organisms } \\
\cline { 2 - 6 } & $\begin{array}{c}\text { Pythium } \\
\text { apanidermatum }\end{array}$ & $\begin{array}{c}\text { Phytophthora } \\
\text { capsici }\end{array}$ & $\begin{array}{c}\text { Macrophomina } \\
\text { phaseolina }\end{array}$ & $\begin{array}{c}\text { Fusarium } \\
\text { udum }\end{array}$ & $\begin{array}{c}\text { Aspergillus } \\
\text { niger }\end{array}$ \\
\hline $\mathbf{T}_{\mathbf{1}}-\mathbf{7 0 \%}$ ethanol & - & - & - & + & + \\
\hline $\mathbf{T}_{\mathbf{2}}-$ Methanol & - & - & - & + & + \\
\hline $\mathbf{T}_{\mathbf{3}}-$ Acetone & - & - & - & + & \\
\hline $\mathbf{T}_{\mathbf{4}}-$ Hexane & - & - & - & - & - \\
\hline $\mathbf{T}_{\mathbf{5}}-$ Petroleum ether & - & - & + & + & - \\
\hline $\mathbf{T}_{\mathbf{6}}-$ Ethyl acetate & + & + & - & - & - \\
\hline $\mathbf{T}_{\mathbf{7}}-$ Dichloromethane & - & - & - & - & - \\
\hline $\mathbf{T}_{\mathbf{8}}-$ Aqueous extract & - & - & + & + & + \\
\hline $\mathbf{T}_{\mathbf{9}}-$ Positive control & + & + & - & - & - \\
\hline $\mathbf{T}_{\mathbf{1 0}}-$ Negative control & - & - & Positive control: Ketaconazole & Negative control: \\
\hline$-:$ No activity & +: Activity & recorded & & & Respective solvents \\
\hline
\end{tabular}


Table.2 Determination of inhibition zone of different solvent extracts of Andrographis echioides (L.) Nees leaves

\begin{tabular}{|c|c|c|c|c|c|}
\hline \multirow[t]{3}{*}{ Test samples } & \multicolumn{5}{|c|}{ Zone of inhibition (cm) } \\
\hline & \multicolumn{5}{|c|}{ Test organisms } \\
\hline & $\begin{array}{c}\text { Pythium } \\
\text { apanidermatum }\end{array}$ & $\begin{array}{c}\text { Phytophthora } \\
\text { capsici }\end{array}$ & $\begin{array}{c}\text { Macrophomina } \\
\text { phaseolina }\end{array}$ & $\begin{array}{c}\text { Fusarium } \\
\text { udum }\end{array}$ & $\begin{array}{c}\text { Aspergillus } \\
\text { niger }\end{array}$ \\
\hline$T_{1}-70 \%$ ethanol & NT & NT & NT & $1.9,2.0$ & $2.2,2.3$ \\
\hline $\mathbf{T}_{2}-$ Methanol & NT & NT & NT & $2.2,2.3$ & $2.7,2.6$ \\
\hline $\mathbf{T}_{3}-$ Acetone & NT & NT & $2.4,2.1$ & $2.5,2.6$ & NT \\
\hline$T_{4}$ - Ethyl acetate & $2.8,2.8$ & $2.5,2.7$ & $3.5,3.6$ & $3.2,3.3$ & 3.3, 3.4 \\
\hline $\mathrm{T}_{5}$ - Positive control & $2.9,3.0$ & $2.6,2.7$ & $3.4,3.5$ & $3.3,3.5$ & $3.2,3.3$ \\
\hline$T_{6}$ - Negative control & - & - & - & - & - \\
\hline NT: Not tested & $-:$ No activity & \multicolumn{2}{|c|}{ Positive control: Ketaconazole } & \multicolumn{2}{|c|}{$\begin{array}{c}\text { Negative control: Respective } \\
\text { solvents }\end{array}$} \\
\hline
\end{tabular}

Table.3 Determination of Minimum Inhibitory Concentration (MIC) for ethyl acetate extract of Andrographis echioides (L.) Nees leaves and Ketaconazole

\begin{tabular}{|c|c|c|c|c|c|c|c|c|}
\hline \multirow[t]{2}{*}{ Organisms } & \multicolumn{2}{|c|}{ Dilution 1} & \multicolumn{2}{|c|}{ Dilution 2} & \multicolumn{2}{|c|}{ Dilution 3} & \multicolumn{2}{|c|}{ Dilution 4} \\
\hline & $\begin{array}{l}\text { Ethyl } \\
\text { acetate } \\
\text { extract }\end{array}$ & $\begin{array}{c}\text { Ketaco- } \\
\text { nazole }\end{array}$ & $\begin{array}{c}\text { Ethyl } \\
\text { acetate } \\
\text { extract }\end{array}$ & $\begin{array}{c}\text { Ketaco- } \\
\text { nazole }\end{array}$ & $\begin{array}{c}\text { Ethyl } \\
\text { acetate } \\
\text { extract }\end{array}$ & $\begin{array}{c}\text { Ketaco- } \\
\text { nazole }\end{array}$ & $\begin{array}{l}\text { Ethyl } \\
\text { acetate } \\
\text { extract }\end{array}$ & $\begin{array}{c}\text { Ketaco- } \\
\text { nazole }\end{array}$ \\
\hline Pythium apanidermatum & NG & NG & G & NG & G & G & G & G \\
\hline Phytophthora capsici & NG & NG & G & NG & G & G & G & G \\
\hline $\begin{array}{l}\text { Macrophomina } \\
\text { phaseolina }\end{array}$ & NG & NG & NG & G & G & G & G & G \\
\hline Fusarium udum & NG & NG & G & NG & G & G & G & $\mathbf{G}$ \\
\hline Aspergillus niger & NG & NG & NG & NG & G & $\mathrm{G}$ & G & $\mathbf{G}$ \\
\hline Dilution 1: $1000 \mathrm{ppm}$ & \multicolumn{2}{|c|}{ Dilution 2: 100 ppm } & \multicolumn{2}{|c|}{ Dilution 3: 10 ppm } & \multicolumn{2}{|c|}{ Dilution 4: 1 ppm. } & $\begin{array}{l}\text { NG: No } \\
\text { growth }\end{array}$ & $\begin{array}{l}\text { G: } \\
\text { Growth }\end{array}$ \\
\hline
\end{tabular}

Plate.1 Antifungal activity of Andrographis echioides (L.) Nees
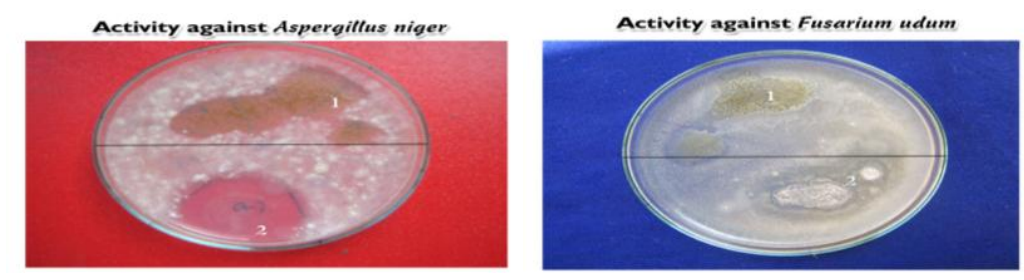

Activity against Macrophomina phaseolina

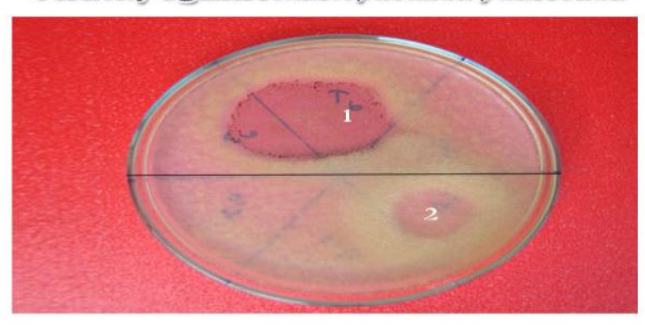

1. Leat extract
2. Positive control 
The hexane, petroleum ether, dichloromethane and aqueous extracts did not produce any activity. This might have resulted from the lack of solubility of the active constituents in these solutions (Romero et al., 2005).

\section{Inhibition zone of different solvent extracts}

The inhibition zone of different solvent extracts of Andrographis echioides leaves was determined by agar well diffusion method. The diameter of inhibition zone of ethanol extract $\left(\mathrm{T}_{1}\right)$ against Fusarium udum and Aspergillus niger was found to be $1.9,2.0 \mathrm{~cm}$ and $2.2,2.3 \mathrm{~cm}$ respectively. The methanol extract $\left(\mathrm{T}_{2}\right)$ produced the inhibition zone of about 2.2, $2.3 \mathrm{~cm}$ and $2.7,2.6 \mathrm{~cm}$ diameter against Fusarium udum and Aspergillus niger. The ethyl acetate extract $\left(\mathrm{T}_{4}\right)$ produced inhibition zone of diameter equal to the positive control against all the selected fungal pathogens (Table 2). The negative control did not produce any inhibition zone against the fungal pathogens.

\section{Determination of Minimum Inhibitory Concentration (MIC)}

Four different dilutions of ethyl acetate extract and Ketaconazole viz., 1000 ppm, 100 ppm, $10 \mathrm{ppm}$ and $1 \mathrm{ppm}$ were tested to determine the minimum inhibitory concentration. It was evident that both the ethyl acetate extract and Ketaconazole inhibited the growth of all the fungal pathogens in the dilution one (1000 ppm). In the dilution $2(100 \mathrm{ppm})$, the Ketaconazole exhibited activity against all the pathogens except Macrophomina phaseolina (Table 3) whereas the ethyl acetate extract exhibited activity against Macrophomina phaseolina and Aspergillus niger (Table 3 and Plate 1). No activity was recorded with the other two dilutions of Ketaconazole and ethyl acetate extract.
In conclusion the anti-microbial activity depends on numerous factors like plant material, techniques employed, growth medium and microorganisms tested. Though, there was nil inhibition at lower concentrations (10 ppm and $1 \mathrm{ppm})$ of ethyl acetate extract, it was hoped that they might produce comparable effect on further purifications and/or isolation of the active constituents. The study of Andrographis echioides as anti-microbial agent was found necessary for gaining insight into this medicinal flora and its real value, for which the studies on mechanisms of action, interactions with antibiotics or other medicinal plants or compounds and the pharmacokinetic profile of the extracts should be given high priority. The extract could be utilized for preparing economic and effective herbal drugs for pathogenic infection and lead to the identification of active ingredients which is the need of the hour, because successful prediction of lead molecule and its properties as a drug at the onset of drug discovery will pay off later in drug development.

\section{References}

Atta-ur-Rahman and Choudhary MI. 1995. Diterpenoid and steroidal alkaloids. Nat. Prod. Rep. 12: 361-379.

Eisenberg, D.M., R.C. Kessler, C. Foster, F.E. Norlock, D.R. Calkins and T.L. Delbanco. 1993. Unconventional medicine in the United States. N. Engl. J. Med., 328: 246-252.

Geissman, T.A. 1963. Flavonoid compounds, tannins, lignins and related compounds. In: Pyrrole pigments, isoprenoid compounds and phenolic plant constituents. (Eds.) Florkin, M. and E.H. Stotz, Elsevier, NewYork, 9: 265.

Ghosh, M., D. Thangamani, M. Thapliyal, R. Yasodha and K. Gurumurthi. 2004. Isolation of Andrographis paniculata 
Leaf Protein with Anti-fungal Property. Acta Phytopathologica et Entomologica Hungarica, 39(4): 377-381.

Guhabakshi GN, Sensarma P, Pal DC. 1999. A Lexicon of Medicinal Plants in India. NAYA PROKASH, Calcutta.

Parez, C., M. Pauli and P. Bazevgue. 1990. An antibiotic assay by the agar well diffusion method. Acta Biologiae et Medicine Experimentalis, 15: 113-115.
Romero CD, Chopin SF, Buck G, Martinez E, Garcia M, Bixby L. 2005. Antibacterial properties of common herbal remedies of the south west. Journal of Ethnopharmacology 99: 253-257.

Schultes, R.E. 1978. The Kingdom of Plants. In: Medicines from the Earth. (Ed.) Thomson, W.A.R. McGraw-Hill Book Co., NewYork: 208.

\section{How to cite this article:}

Hemalatha, P., V. Sivakumar, R. Parimaladevi and Tilak, M. 2020. Studies on Anti-fungal Activity of Leaf Extracts of Andrographis echioides (L.) Nees. Int.J.Curr.Microbiol.App.Sci. 9(10): 3853-3858. doi: https://doi.org/10.20546/ijcmas.2020.910.443 